\title{
PENDUGAAN UMUR SIMPAN SELAI APEL HIJAU LEMBARAN MENGGUNAKAN METODE ACCELERATED SHELF LIFE TESTING (ASLT) DENGAN PENDEKATAN ARRHENIUS
}

\author{
Estimation Saving Green Aples Sheet Use Accelerated Shelf Life Testing (ASLT) Method with \\ Arrhenius Approach
}

\author{
Slamet Hadi Kusumah \\ Program Studi Teknologi Pangan, Fakultas Teknik \\ Universitas Islam Al-Ihya Kuningan, Jawa Barat, Indonesia \\ E-mail: slamet.hadikusumah@gmail.com
}

\begin{abstract}
ABSTRAK
Selai apel hijau lembaran merupakan produk pengembangan selai apel yang dimodifikasi menjadi bentuk lembaran. Tujuan pembuatan selai apel hijau lembaran ini untuk mempermudah konsumen dalam mengkonsumsi selai. Produk selai apel hijau lembaran ini lebih praktis dan mudah dalam penyajiannya jika dibandingkan dengan selai apel pada umumnya. Penggunaan agar-agar dapat menghasilkan tekstur selai yang membentuk gel sehingga selai apel dapat dicetak menjadi lembaran. Tujuan dari penelitian ini adalah untuk mengetahui umur simpan selai apel hijau lembaran menggunkan metode Accelerated Shelf Life Testing (ASLT) dengan Pendekatan Arrhenius. Penyimpanan dilakukan pada suhu $20{ }^{\circ} \mathrm{C}, 25{ }^{\circ} \mathrm{C}$, dan $30^{\circ} \mathrm{C}$. Uji sensori dan uji total kapang dilakukan setiap selang waktu 3 hari. Uji sensori dihentikan pada hari ke- 9 karena total kapang sudah mencapai batas maksimum yaitu $5 \times 10^{1}$ koloni/g. Nilai $R^{2}$ pada parameter warna ordo satu merupakan nilai terbesar. Nilai $R^{2}$ parameter warna adalah 0,882 yang digunakan untuk menghitung umur simpan selai apel lembaran dengan persamaan Arrhenius y $=-10152 x+30,63$. Hasil perhitungan umur simpan selai apel lembaran berdasarkan parameter warna melalui pendekatan Arrhenius menunjukan bahwa selai apel lembaran dapat bertahan hingga 20 hari pada suhu $20^{\circ} \mathrm{C}$, 11 hari pada suhu $25^{\circ} \mathrm{C}$, dan 6 hari pada suhu $30^{\circ} \mathrm{C}$.
\end{abstract}

Kata kunci: selai apel hijau lembaran, umur simpan, ASLT, arrhenius

\begin{abstract}
Green apple jam sheet is a product of apple jam development that is modified into sheet form. The purpose of making this green apple jam sheet is to facilitate consumers in consuming jam. This green apple jam product is more practical and easy to serve compared to apple jam in general. The use of gelatin can produce a gel texture that forms a gel so that apple jam can be printed into sheets. The purpose of this study was to determine the shelf life of green apple jam sheets using the Accelerated Shelf Life Testing (ASLT) method with the Arrhenius Approach. Storage is carried out at a temperature of $20^{\circ} \mathrm{C}, 25^{\circ} \mathrm{C}$, and $30^{\circ} \mathrm{C}$. Sensory test and total mold test were carried out every 3 days intervals. Sensory test was stopped on the 9th day because the total mold had reached the maximum limit of $5 \times 10^{1}$ colonies $/ \mathrm{g}$. The value of $R^{2}$ in the first order color parameter is the largest value. The $R^{2}$ value of the color parameter is 0.882 which is used to calculate the shelf life of sheet apple jam with the Arrhenius equation $y=-10152 x+30.63$. Calculation results of shelf life of sheet apple jam based on color parameters through the Arrhenius approach show that sheet apple jam can last up to 20 days at $20^{\circ} \mathrm{C}, 11$ days at $25^{\circ} \mathrm{C}$, and 6 days at $30^{\circ} \mathrm{C}$.
\end{abstract}

Keywords: green apple jam sheet, shelf life, ASLT, arrhenius 


\section{PENDAHULUAN}

Selai merupakan produk makanan semi basah yang dapat dioleskan yang dibuat dari pengolahan buah-buahan, gula dengan atau tanpa penambahan bahan pangan lain dan bahan tambahan pangan yang diizinkan. Bentuk selai oles yang sudah umum terdapat di pasaran dianggap kurang praktis dalam penyajiannya. Oleh karena itu, pembuatan selai lembaran merupakan modifikasi dari selai oles menjadi selai lembaran yang kompak, plastis, dan tidak lengket sehingga memudahkan penyajiannya (Yenrina, et. al, 2009).

Selai lembaran adalah selai yang berbentuk lembaran sesuai permukaan roti, tidak cair atau terlalu lembek, namun juga tidak terlalu kaku sehingga diperlukan bahan tambahan berupa hidrokolid sebagai penguat tekstur. Salah satu bahan tambahannya adalah hidrokoloid turunan rumput laut merah yaitu agar-agar. Pemanfaatan agar-agar sebagai bahan tambahan selai diharapkan mampu mengubah teksur selai menjadi lembaran yang disukai. Selain itu diharapkan produk ini mampu menjadi salah satu alternatif diversifikasi pengolahan pangan semi basah yang telah ada (Ramadan, 2011).

Selai sebagai salah satu jenis pangan semi basah, memiliki beberapa titik kritis dalam proses dan paska pengolahannya, salah satunya adalah penurunan mutu selai selama proses penyimpanan hingga produk tersebut dinyatakan kadaluwarsa. Penentuan aspek kadaluwarsa suatu produk pangan sangat penting untuk menjaga keamanan serta memastikan produk tersebut masih layak dikonsumsi. Masih banyak produk pangan yang belum mencantumkan batas atau umur simpan produk tersebut pada kemasannya, salah satunya selai apel lembaran ini. Padahal umur simpan merupakan hal yang cukup penting karena salah satu ciri produk bermutu tinggi dan berdaya saing adalah memiliki umur simpan yang jelas.

Menurut Rahayu dan Arpah (2003) model yang sesuai dengan pendugaan umur simpan dari selai adalah dengan parameter sensori berdasarkan kemunduran mutu rasa, aroma, kriteria total kapang, dan ketengikan produk. Semakin tinggi suhu penyimpanan maka laju reaksi berbagai senyawa kimia akan semakin meningkat, karena itu dalam menduga kecepatan penurunan mutu bahan pangan selama penyimpanan, faktor suhu harus selalu diperhatikan (Syarief dan Halid 1993).

Selai apel lembaran merupakan produk semi basah dengan masa simpan terbatas sehingga perlu adanya penetapan masa simpan untuk menjamin mutu selai saat dikonsumsi. Berdasarkan uraian di atas, diperlukan kajian mengenai penentuan umur simpan selai apel lembaran yang dapat dilakukan melalui metode Accelerated Shelf Life Testing (ASLT) dengan pendekatan arrhenius.

\section{METODE}

\section{Alat dan Bahan}

Alat yang digunakan dalam penelitian ini meliputi blender, timbangan, pengaduk, sendok, kompor, panci, kantong plastik, penggiling, oven, pisau, saringan, inkubator, termometer, dan hotplate. Bahan yang digunakan dalam penelitian ini adalah buah apel hijau (Mallus sylvestris mill), karagenan, gula, asam sitrat, air, dan bahan penunjang lainnya.

\section{Tahapan Penelitian}

\section{Pembuatan Selai Apel Lembaran}

Pembuatan selai apel lembaran menggunakan buah apel (Mallus sylvestris mill), gula, asam sitrat, dan agar-agar. Proses pembuatan dan komposisi bahan yang digunakan dalam penelitian ini memodifikasi penelitian pembuatan selai apel lembaran yang telah dilakukan oleh Rahayu (2013). Proses pembuatan selai pada penelitian pendahuluan tersaji pada Gambar 1. 


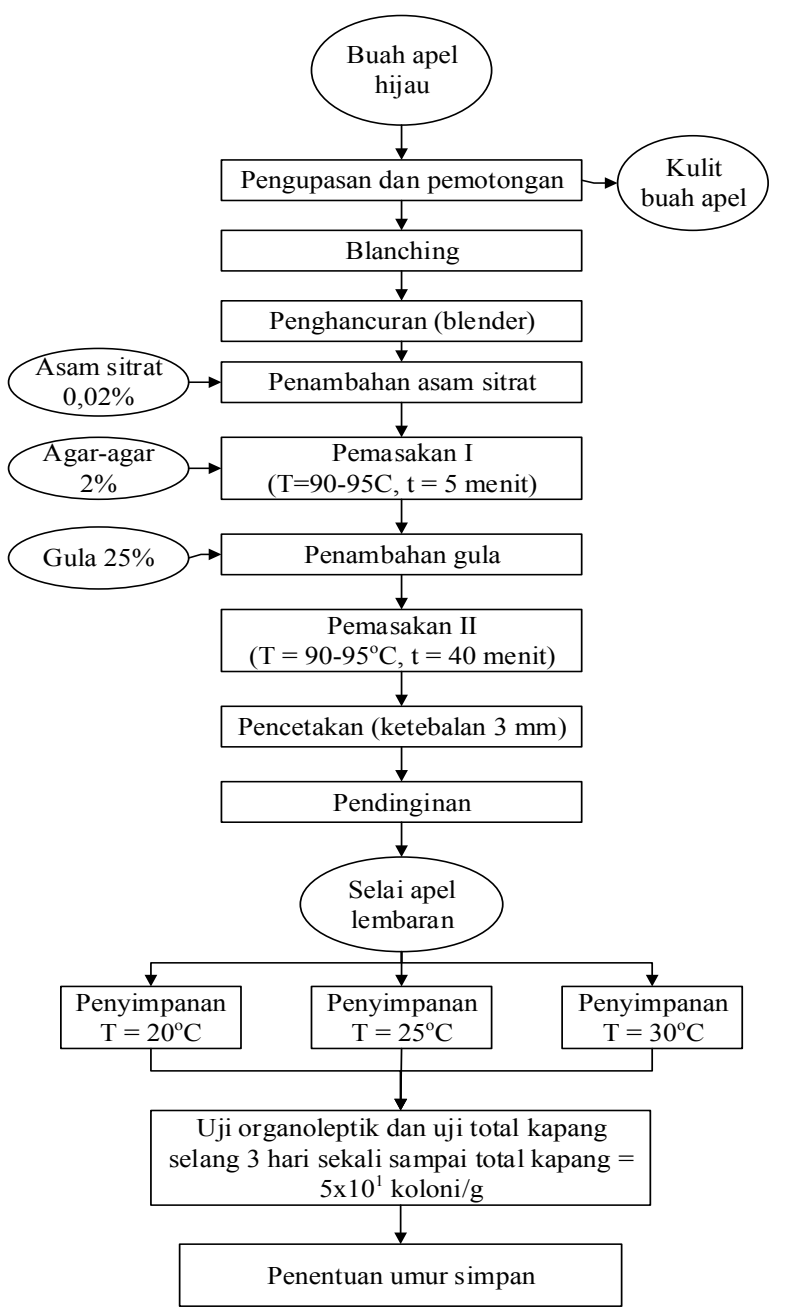

Gambar 1. Tahapan Penelitian (Modifikasi Rahayu, 2013)

\section{Uji Sensori dan Uji Total Kapang}

Uji sensori dilakukan tiap selang waktu 3 (tiga) hari pada sampel selai apel lembaran yang disimpan pada suhu $20^{\circ} \mathrm{C}, 25^{\circ} \mathrm{C}$, dan $30^{\circ} \mathrm{C}$. Karakteristik sensori selai apel lembaran yang diamati meliputi parameter kenampakan, warna, aroma, rasa, dan tekstur.

Penilaian parameter ini dilakukan pada 15 orang panelis. Kriteria penilaian sebagai berikut:

1 = Tidak Baik

2 = Cukup Baik

$3=$ Baik

$4=$ Sangat Baik

Bersamaan dengan itu dilakukan pengujian total kapang pada sampel yang sama sesuai dengan selang waktu sesuai uji sensori. Pengujian dihentikan ketika jumlah koloni kapang mencapai batas maksimum yaitu $5 \times 10^{1} \mathrm{koloni} / \mathrm{g}$ (Ramadan, 2011).

\section{Penentuan Umur Simpan}

Metode penelitian yang digunakan dalam penelitian ini menggunakan analisis regresi. Penentuan parameter kunci dengan melihat parameter yang mempunyai $R^{2}$ terbesar. Umur simpan selai apel lembaran dihitung dengan persamaan kinetika reaksi berdasarkan ordo reaksinya. Data dari analisis setiap parameter diplotkan terhadap waktu (hari) dan didapatkan persamaan regresi liniernya sehingga diperoleh tiga persamaaan untuk tiga kondisi suhu penyimpanan produk $y=b x+a$. 
Dimana $y=$ nilai karakteristik selai apel lembaran, $x$ = waktu penyimpanan (hari), $b=$ laju perubahan karakteristik (slope atau laju penurunan mutu $=k$ ), dan $a=$ nilai karakteristik awal selai apel lembaran. Pemilihan ordo reaksi untuk suatu parameter dilakukan dengan cara membandingkan koefisien determinasi $\left(R^{2}\right)$ tiap persamaan regresi pada suhu yang sama). Ordo reaksi dengan nilai $R^{2}$ yang lebih besar merupakan orde reaksi yang digunakan oleh parameter tersebut. Hasil dari persamaan tersebut diperoleh nilai konstanta $k_{0}$ yang merupakan faktor eksponensial dan nilai energi aktivasi (Ea) reaksi perubahan karakteristik selai apel lembaran kemudian ditentukan model persamaan laju reaksi $(\mathrm{k})$ perubahan karakteristik selai apel lembaran yang dihitung dengan rumus $\mathrm{k}=\mathrm{k}_{0}$.e-E/RT. Umur simpan selai apel lembaran dihitung dengan persamaan kinetika reaksi berdasarkan ordo reaksinya.

$$
\begin{aligned}
& t=(A 0-A t) / k \ldots \ldots \ldots \ldots \ldots \ldots . .(\text { Pers. Ordo Nol) } \\
& t=\ln (A 0-A t) / k \ldots \ldots \ldots \ldots . . .(\text { Pers. Ordo Satu })
\end{aligned}
$$

dimana:

$\mathrm{t}=$ umur simpan produk (hari)

$A_{0}=$ nilai atribut mutu di awal (hari ke- 0)

$A_{t}=$ nilai atribut mutu di akhir (hari ke- $t$ )

$\mathrm{k}=$ konstanta penurunan mutu

Pemilihan suhu $20^{\circ} \mathrm{C}, 25^{\circ} \mathrm{C}$, dan $30^{\circ} \mathrm{C}$ merupakan contoh penyimpanan yang akan menjadi model linear sederhana dari metode Arrhenius. Sesuai pada prinsipnya, dilakukan akselerasi terhadap suhu sehingga berdasarkan hukum kinetika maka reaksi yang ada juga akan meningkat. Peningkatan suhu sebesar $10^{\circ} \mathrm{C}$ akan meningkatkan dua kali reaksi pada produk (Ramadan, 2011).

\section{HASIL DAN PEMBAHASAN}

\section{Karakteristik Sensori Selai Apel Lembaran}

\section{Kenampakan}

Berdasarkan Tabel 1, pada hari ke-0 kenampakan selai apel lembaran memiliki nilai sangat tinggi pada suhu penyimpanan $20^{\circ} \mathrm{C}, 25^{\circ} \mathrm{C}$, dan $30^{\circ} \mathrm{C}$ yaitu masing-masing 3,$80 ; 3,73$; dan 3,73 . Hal ini menunjukan bahwa selai apel lembaran dapat diterima oleh konsumen.

Tabel 1. Hasil uji sensori parameter kenampakan

\begin{tabular}{cccc}
\hline Hari ke- & \multicolumn{3}{c}{ Suhu $\left({ }^{\circ} \mathbf{C}\right)$} \\
\cline { 2 - 4 } & $\mathbf{2 0}$ & $\mathbf{2 5}$ & $\mathbf{3 0}$ \\
\hline 0 & 3.80 & 3.73 & 3.73 \\
\hline 3 & 3.53 & 2.93 & 2.40 \\
\hline 6 & 3.40 & 2.20 & 1.73 \\
\hline 9 & 3.33 & 2.00 & 1.53 \\
\hline
\end{tabular}

Penambahan gula $25 \%$ dan asam sitrat 0,02\% menghasilkan kenampakan selai apel hijau lembaran yang disukai oleh panelis karena selai tersebut memiliki warna yang cerah dengan permukaan yang utuh dan rapih. Kenampakan selai apel hijau lembaran mengalami penurunan mutu setelah disimpan selama 9 hari. Selama proses penyimpanan selai apel lembaran terjadi perubahan kenampakan selai menjadi gelap dan rusak. Nilai yang diberikan panelis terhadap parameter kenampakan selai adalah 3,33; 2,00; dan 1,53 berturut-turut pada suhu penyimpanan $20^{\circ} \mathrm{C}, 25^{\circ} \mathrm{C}$, dan $30^{\circ} \mathrm{C}$.

Selai merupakan makanan semi basah yang mudah untuk ditumbuhi kapang dan jamur. Namun, kenampakan selai apel hijau lembaran pada suhu penyimpanan $20^{\circ} \mathrm{C}$ masih baik dan tidak mengalami kerusakan. Semakin tinggi suhu penyimpanan maka laju kerusakan selai apel lembaran akan semakin cepat sehingga akan mempersingkat umur simpannya. 


\section{Warna}

Berdasarkan Tabel 2, nilai warna yang dihasilkan pada hari ke-0 untuk suhu penyimpanan $20^{\circ} \mathrm{C}, 25^{\circ} \mathrm{C}$, dan $30^{\circ} \mathrm{C}$ yaitu masing-masing 3,$60 ; 3,46$, dan 3,40 , hal ini menunjukan bahwa panelis menerima produk tersebut.

Tabel 2. Hasil uji sensori parameter warna

\begin{tabular}{cccc}
\hline \multirow{2}{*}{ Hari ke- } & \multicolumn{3}{c}{ Suhu $\left({ }^{\circ} \mathbf{C}\right)$} \\
\cline { 2 - 4 } & $\mathbf{2 0}$ & $\mathbf{2 5}$ & $\mathbf{3 0}$ \\
\hline 0 & 3.60 & 3.46 & 3.40 \\
\hline 3 & 3.46 & 3.00 & 2.53 \\
\hline 6 & 3.33 & 2.53 & 2.00 \\
\hline 9 & 3.13 & 2.33 & 1.86 \\
\hline
\end{tabular}

Pada suhu penyimpanan $25^{\circ} \mathrm{C}$ terjadi penurunan nilai warna pada hari ke- 6 dan ke- 9 , sedangkan pada suhu penyimpanan $30^{\circ} \mathrm{C}$ terjadi penurunan nilai warna pada hari ke-3, ke-6, dan ke-9. Proses perubahan warna selama proses pemasakan selai diduga disebabkan oleh tiga hal, yaitu kehilangan atau rusaknya pigmen dari buah tersebut, konfigurasi proses pencoklatan, dan diskolorasi warna (Endan dan Javanmard 2010).

Proses pencokelatan yang dialami oleh apel merupakan proses pencokelatan enzimatik yang dipengaruhi oleh kerja enzim fenolase. Apabila enzim tersebut mengalami kontak dengan oksigen di udara, fenolase akan mengkatalisis konversi biokimia dari komponen fenolik yang ada pada apel sehingga komponen tersebut berubah menjadi pigmen coklat atau melanin. Proses ini pada umumnya terjadi pada $\mathrm{pH}$ antara 5,0-7,0 dan pada temperatur yang cenderung hangat.

Terdapat dua reaksi dalam proses pencokelatan enzimatik yaitu reaksi Cresolase dan Catecholase. Reaksi Catecholase terjadi segera setelah terbentuknya senyawa odifenol, tanpa memerlukan keberadaan oksigen ataupun enzim fenolase. Setelah senyawa oquinone terbentuk, senyawa o-difenol akan mengalami hidroksilasi menjadi senyawa trifenolik yang akan bereaksi lebih jauh dengan o-quinone dalam proses pembentukan melanin coklat pada apel (Gabriella, 2011).

\section{Aroma}

Aroma selai apel lembaran yang dihasilkan sudah baik. Aroma buah apel dan gula yang tercium sudah seimbang sehingga panelis menyukai dan menerima produk. Nilai aroma yang dihasilkan adalah 3,40 - 3,53 pada hari ke-0 (Tabel 3).

Tabel 3. Hasil uji sensori parameter aroma

\begin{tabular}{cccc}
\hline \multirow{2}{*}{ Hari ke- } & \multicolumn{3}{c}{ Suhu $\left({ }^{\circ} \mathbf{C}\right)$} \\
\cline { 2 - 4 } & $\mathbf{2 0}$ & $\mathbf{2 5}$ & $\mathbf{3 0}$ \\
\hline 0 & 3.53 & 3.46 & 3.40 \\
\hline 3 & 3.40 & 2.93 & 1.93 \\
\hline 6 & 3.26 & 2.20 & 1.80 \\
\hline 9 & 3.13 & 1.93 & 1.60
\end{tabular}

Terjadi penurunan nilai pada hari ke-3, ke-6, dan ke-9 saat selai apel disimpan pada kondisi suhu penyimpanan $25^{\circ} \mathrm{C}$ dan $30^{\circ} \mathrm{C}$. Aroma khas buah pada selai dipengaruhi oleh aroma gula yang membentuk karamel yang menutupi aroma buah apel.

Karamel merupakan salah satu hasil dari reaksi karamelisasi yang terjadi selama proses pengolahan. Reaksi karamelisasi terjadi apabila beberapa kondisi terpenuhi meliputi kondisi suhu tinggi $100-160^{\circ} \mathrm{C}$, keberadaan katalis berupa kondisi derajat keasaman (basa, asam, garam atau tingkat kemurnian), keberadaan karbohidrat lain (sukrosa, glukosa, dan fruktosa) (Quintas et al. 2007) 


\section{Rasa}

Parameter rasa dipengaruhi oleh beberapa faktor, diantaranya adalah senyawa kimia, suhu, konsentrasi dan interaksi dengan komponen rasa lain (Winarno 2008). Rasa selai apel hijau lembaran yang dihasilkan sudah baik. Rasa yang dihasilkan sudah seimbang dengan komposisi rasa manis dan asam.

Tabel 4. Hasil uji sensori parameter rasa

\begin{tabular}{cccc}
\hline \multirow{2}{*}{ Hari ke- } & \multicolumn{3}{c}{ Suhu $\left({ }^{\circ} \mathbf{C}\right)$} \\
\cline { 2 - 4 } & $\mathbf{2 0}$ & $\mathbf{2 5}$ & $\mathbf{3 0}$ \\
\hline 0 & 3.60 & 3.46 & 3.40 \\
\hline 3 & 3.33 & 3.20 & 0.80 \\
\hline 6 & 2.86 & 2.46 & 0.60 \\
\hline 9 & 2.40 & 2.06 & 0.13 \\
\hline
\end{tabular}

Penyimpanan selai apel hijau lembaran pada suhu $30^{\circ} \mathrm{C}$ menyebabkan pertumbuhan kapang pada permukaan selai apel. Hal ini menyebabkan banyak panelis yang tidak memberikan nilai pada parameter rasa. Setelah hari ke-9, nilai parameter rasa ini mengalami penurunan drastis yaitu 2,40; 2,06; dan 0,13 berturut-turut pada suhu penyimpanan $20^{\circ} \mathrm{C}, 25^{\circ} \mathrm{C}$, dan $30^{\circ} \mathrm{C}$ (Tabel 4).

Rasa yang dihasilkan pada penyimpanan suhu $30^{\circ} \mathrm{C}$ adalah agak pahit dan hambar sedangkan rasa yang dihasilkan pada penyimpanan suhu $20^{\circ} \mathrm{C}$ adalah manis dan asam. Rasa merupakan faktor utama diterima atau tidaknya suatu produk pangan, walaupun suatu produk pangan memiliki penampakan yang menarik, namun rasa akan menjadi faktor akhir yang menentukan diterimanya atau tidaknya suatu produk oleh konsumen.

\section{Tekstur}

Tekstur adalah sekelompok sifat fisik yang ditimbulkan oleh elemen struktural bahan pangan yang dapat dirasa oleh indera peraba (de Man 1997). Tekstur selai apel lembaran yang dihasilkan sudah baik. Tekstur yang dihasilkan sudah membentuk gel, tidak mudah hancur, dan empuk. Tekstur selai apel lembaran memiliki nilai 3,53-3,66 (Tabel 5).

Tabel 5. Hasil uji sensori parameter tekstur

\begin{tabular}{cccc}
\hline \multirow{2}{*}{ Hari ke- } & \multicolumn{3}{c}{ Suhu $\left({ }^{\circ} \mathbf{C}\right)$} \\
\cline { 2 - 4 } & $\mathbf{2 0}$ & $\mathbf{2 5}$ & $\mathbf{3 0}$ \\
\hline 0 & 3.66 & 3.53 & 3.60 \\
\hline 3 & 3.33 & 3.06 & 2.53 \\
\hline 6 & 3.06 & 2.46 & 1.93 \\
\hline 9 & 2.73 & 2.20 & 1.86 \\
\hline
\end{tabular}

Secara umum tekstur selai apel hijau lembaran dipengaruhi oleh konsentrasi agar-agar yang digunakan. Agar-agar memiliki kemampuan membentuk jaringan triple heliks yang mampu merangkap air dan menurunkann aliran fluida dalam adonan yang menyebabkan peningkatan kekuatan gel dari selai. Semakin besar penambahan konsentrasi agar-agar tepung maka gel yang dihasilkan akan semakin kuat atau semakin kenyal (Labropolus et al. 2002).

\section{Hasil Uji Total Kapang}

Tabel 6. Peningkatan total kapang selai apel lembaran

\begin{tabular}{cccc}
\hline \multirow{2}{*}{ Suhu $\left({ }^{\circ} \mathrm{C}\right)$} & \multicolumn{3}{c}{ Jumlah kapang (koloni/g) } \\
\cline { 2 - 4 } & Hari ke-3 & Hari ke-6 & Hari ke-9 \\
\hline 20 & $1 \times 10^{1}$ & $1.5 \times 10^{1}$ & $3 \times 10^{1}$ \\
\hline 25 & $1.5 \times 10^{1}$ & $2.5 \times 10^{1}$ & $4.5 \times 10^{1}$ \\
\hline 30 & $2.5 \times 10^{1}$ & $4 \times 10^{1}$ & $5 \times 10^{1}$ \\
\hline
\end{tabular}


Penyimpanan selai apel lembaran akan dihentikan jika total kapang pada selai jambu biji lembaran telah mencapai batas maksimum yaitu $5 \times 10^{1} \mathrm{koloni} / \mathrm{g}$ (Ramadan, 2011). Pada selai apel lembaran, penyimpanan dihentikan pada hari ke-9 karena total kapang mencapai batas maksimum yaitu $5 \times 10^{1}$ koloni/g (Tabel 6).

\section{Pendugaan umur simpan dengan metode ASLT pendekatan Arrhenius}

Metode pendugaan umur simpan yang dilakukan pada selai apel lambaran ini adalah dengan metode arrhenius. Selai apel disimpan pada tiga suhu yang berbeda yaitu $20^{\circ} \mathrm{C}, 25^{\circ} \mathrm{C}$, dan $30^{\circ} \mathrm{C}$. Setelah selang waktu 3 hari, sampel akan diuji total kapang dan uji hedonik oleh panelis.

Penentuan parameter kunci dengan melihat parameter yang mempunyai $\mathrm{R}^{2}$ terbesar (Syah, 2012). Berdasarkan hasil perhitungan, nilai $R^{2}$ yang terbesar terdapat pada parameter warna dengan ordo satu yaitu dengan nilai 0.882 . Perbandingan nilai $R^{2}$ dapat dilihat pada Tabel 7.

Tabel 7. Persamaan Arrhenius, Nilai Koefisien Korelasi $\left(\mathrm{R}^{2}\right)$ Tiap Parameter

\begin{tabular}{ccccc}
\hline No & Parameter & Ordo & Persamaan Arrhenius & $\mathbf{R}^{2}$ \\
\hline \multirow{2}{*}{1} & Kenampakan & Nol & $\mathrm{y}=-13.159 \mathrm{x}+41.76$ & 0.721 \\
\cline { 3 - 5 } & & Satu & $\mathrm{y}=-18.791 \mathrm{x}+59.71$ & 0.814 \\
\hline \multirow{2}{*}{2} & Warna & Nol & $\mathrm{y}=-6.268 \mathrm{x}+18.60$ & 0.758 \\
\cline { 3 - 5 } & & Satu & $\mathbf{y}=-\mathbf{1 0 . 1 5 2 x}+\mathbf{3 0 . 6 3}$ & $\mathbf{0 . 8 8 2}$ \\
\hline \multirow{2}{*}{3} & Aroma & Nol & $\mathrm{y}=-2.101 . \mathrm{x}+4.447$ & 0.027 \\
\cline { 3 - 5 } & & Satu & $\mathrm{y}=-7.837 \mathrm{x}+22.80$ & 0.279 \\
\hline \multirow{2}{*}{4} & Rasa & Nol & $\mathrm{y}=2.947 \mathrm{x}-11.86$ & 0.741 \\
\cline { 3 - 5 } & & Satu & $\mathrm{y}=5.474 \mathrm{x}-21.45$ & 0.580 \\
\hline 5 & Tekstur & Nol & $\mathrm{y}=-0.9574 \mathrm{x}+1.067$ & 0.082 \\
\cline { 3 - 4 } & & Satu & $\mathrm{y}=-3.718 \mathrm{x}+9.378$ & 0.594 \\
\hline
\end{tabular}

Perhitungan umur simpan ( $\mathrm{t}$ ) selai apel lembaran ini akan diketahui dengan menggunkan persamaan Arrhenius pada parameter warna ordo satu. Persamaan Arrhenius parameter warna ordo satu yaitu $y=-10152 x+30,63$. Persamaan tersebut diubah menjadi persamaan In $\mathrm{k}$, sehingga diperoleh persamaan:

$$
\ln k=[-10152(1 / T)]+30,63
$$

Keterangan:

$\mathrm{k}=$ konstanta penurunan mutu

$\mathrm{t}=\operatorname{suhu}\left({ }^{\mathrm{O}} \mathrm{K}\right)$

Nilai $\mathrm{k}$ dapat diketahui dengan menggunakan persamaan di atas, sehingga diperoleh hasil sebagai berikut

Nilai k pada suhu $20^{\circ} \mathrm{C} \approx 293^{\circ} \mathrm{K}$

In $\mathrm{k}=[-10152(1 / 293)]+30,63$

In $\mathrm{k}=-4,01846$

$k=0,0179$

Nilai k pada suhu $25^{\circ} \mathrm{C} \approx 298^{\circ} \mathrm{K}$

In $\mathrm{k}=[-10152(1 / 298)]+30,63$

In $\mathrm{k}=-3,4371$

$\mathrm{k}=0,0322$

Nilai k pada suhu $30^{\circ} \mathrm{C} \approx 303^{\circ} \mathrm{K}$

In $\mathrm{k}=[-10152(1 / 303)]+30,63$

In $\mathrm{k}=-2,87495$

$\mathrm{k}=0,0564$ 
Penentuan umur simpan selai apel hijau lembaran menggunakan rumus umur simpan ordo satu sebagai berikut.

$\begin{array}{ll}\text { Keterangan: } & \\ & =\text { umur simpan produk (hari) } \\ \mathrm{T} & =\text { nilai rerata mutu di awal (hari ke-0) } \\ \mathrm{A}_{0} & =\text { nilai rerata mutu di akhir (hari } \mathrm{ke}-9) \\ \mathrm{A}_{9} & =\text { konstanta penurunan mutu } \\ \mathrm{k} & \end{array}$

Nilai rerata mutu pada awal dan akhir penyimpanan dapat dilihat pada Tabel 8 berikut ini.

Tabel 8. Nilai rerata mutu awal dan akhir

\begin{tabular}{cccc}
\hline & $\mathbf{A}_{\mathbf{0}}$ & $\mathbf{A}_{\mathbf{9}}$ & $\mathbf{A}_{\mathbf{0}}-\mathbf{A}_{\mathbf{9}}$ \\
\hline Rerata & 3,489 & 2,444 & \\
\hline In Rerata & 1,250 & 0,894 & 0,356
\end{tabular}

Selisih In rerata mutu awal dan akhir selai apel lembaran adalah 0,356. Penentuan umur simpan (t) dapat diketahui dengan membagi selisih In rerata dengan nilai $\mathrm{k}$.

Penentuan umur simpan pada suhu $20^{\circ} \mathrm{C}$

$\mathrm{t}=0,356 / 0,0179$

$\mathrm{t}=19,89 \approx 20$ hari

Penentuan umur simpan pada suhu $25^{\circ} \mathrm{C}$

$\mathrm{t}=0,356 / 0,0322$

$\mathrm{t}=11,05 \approx 11$ hari

Penentuan umur simpan pada suhu $30^{\circ} \mathrm{C}$

$\mathrm{t}=0,356 / 0,0564$

$\mathrm{t}=6,31 \approx 6$ hari

Hasil perhitungan umur simpan selai apel lembaran berdasarkan parameter warna melalui pendekatan Arrhenius menunjukan bahwa selai apel lembaran dapat bertahan hingga 20 hari pada suhu $20^{\circ} \mathrm{C}, 11$ hari pada suhu $25^{\circ} \mathrm{C}$, dan 6 hari pada suhu $30^{\circ} \mathrm{C}$. Kondisi selai apel lembaran yang disimpan pada suhu $20^{\circ} \mathrm{C}$ tidak memiliki perubahan penurunan mutu yang drastis sampai hari ke9. Tidak terjadi kerusakan pada kenampakan, warna, tekstur, aroma, dan rasa selama penyimpanan. Suhu merupakan faktor yang berpengaruh terhadap perubahan makanan.

Semakin tinggi suhu penyimpanan maka laju reaksi berbagai senyawa kimia akan semakin meningkat, karena itu dalam menduga kecepatan penurunan mutu bahan pangan selama penyimpanan, faktor suhu harus selalu diperhatikan (Syarief dan Halid 1993). Usaha yang dapat dilakukan untuk mempertahankan umur simpan selai apel lembaran ini adalah memperlambat respirasi dan menangkap gas etilen yang terbentuk. Pendinginan mempunyai sifat mengawetkan bahan makanan karena dengan suhu yang rendah dapat menghambat pertumbuhan mikroba pembusuk yang terdapat dalam selai apel lembaran ini. Suhu rendah yang mendekati titik beku sangat efektif dalam mengurangi laju respirasi yang terjadi.

Kapang merupakan kontaminan utama yang penting di olahan buah. Spora kapang akan inaktif selama proses pemasakan, namun akan kembali aktif dalam kondisi optimumnya (Nieminen et al. 2008). Kapang yang tumbuh dalam produk buah-buah seperti pada buah apel dan selai apel hijau lembaran adalah Penicillium Ekspansum (Syah, 2012).

Berdasarkan hasil uji hedonik terlihat bahwa semakin tinggi suhu dan semakin lama masa penyimpanan nilai rataan kenampakan, warna, aroma, rasa, dan tekstur semakin menurun. Rasa manis selai di awal penyimpanan akan mulai hilang di akhir penyimpanan pada suhu $30^{\circ} \mathrm{C}$, hal ini diduga karena aktivitas mikroba yang ada dalam selai telah meningkat jumlahnya. Mikroba memanfaatkan kadar gula yang cukup tinggi sebagai nutrisi hidupnya, yang akhirnya akan secara tidak langsung mempengaruhi rasa dari selai apel hijau lembaran.

Keberadaan mikroba, khususnya kapang dapat mendegradasi makromolekul (karbohidrat, protein, dan lipida) menjadi senyawa-senyawa organik. Molekul gula dan karbohidrat lainnya dapat berubah manjadi asam akibat adanya metabolisme karbohidrat menjadi asam dan alkohol (de Man 1997). Hasil pemecahan suatu komponen kimia yang terdapat di dalam substrat berbeda-beda bergantung pada jenis substrat dan spesies mikrobanya. 
Pemecahan karbohidrat oleh mikroba dapat menghasilkan asam-asam organik (asam laktat, asetat, butirat, atau propionat), produk-produk netral (aseton, butil alkohol, atau etil alkohol), dan bermacam-macam gas (metana, hidrogen, atau karbondioksida). Hasil pemecahan komponen tersebut akan mempengaruhi $\mathrm{pH}$ (Fardiaz 1989) dan nantinya secara tidak langsung akan mempengaruhi kenampakan, aroma, warna, rasa, dan tekstur selama masa penyimpanan.

Metabolisme jaringan yang hidup merupakan fungsi dari suhu di sekelilingnya. Organisme hidup memerlukan suhu yang optimal bagi perkembangbiakannya. Penggunaan suhu rendah dapat dilakukan untuk menghambat atau mencegah reaksi-reaksi kimia, reaksi enzimatis atau pertumbuhan mikroba, sedangkan suhu yang tinggi akan merusak mikroorganisme.

\section{KESIMPULAN}

Umur simpan dipengaruhi suhu penyimpanan dengan persamaan Arrhenius $y=-10152 x+$ 30,63 dengan nilai $R^{2}=0,882$. Pada suhu $30^{\circ} \mathrm{C}$ laju kerusakan terjadi paling cepat sedangkan pada suhu $20^{\circ} \mathrm{C}$ laju kerusakannya paling lambat. Hasil perhitungan umur simpan selai apel lembaran melalui pendekatan Arrhenius menunjukan bahwa selai apel lembaran dapat bertahan hingga 20 hari pada suhu $20^{\circ} \mathrm{C}, 11$ hari pada suhu $25^{\circ} \mathrm{C}$, dan 6 hari pada suhu $30^{\circ} \mathrm{C}$.

\section{DAFTAR PUSTAKA}

De Man, JM. (1997). Kimia Makanan. Kosasih Padmawinata, Penerjemah. Bandung: ITB. hal 175348.

Endan J and Javanmard M. 2010. A Survey on Rheological Properties of Fruit Jams. Journal of Chemical Engineering and Applications. I (1). Hal 221.

Fardiaz D. (1989). Hidrokoloid. Laboratorium Kimia dan Biokimia Pangan. Pusat Antar Universitas Pangan dan Gizi. Institut Pertanian Bogor. hal 56.

Gabriella. (2011). Proses Pencokelatan Pada Buah Apel. Gramedia: Jakarta

Labropolus KC, DE Niesz, SC Danfotrh, PG Kevrekidis. 2002. Dynamic Rheology or Agar Gels: Theory and Experiments. Part I. Development of a Rheological Model. Carbohydrate Polymer. Elsevier 393-406.

Nieminen T, Neubauer P, Sivela S, Vatano S, Sifverberg P, Salonen MS. (2008). Volatile Compounds Produced by Fungi in Strawberry Jam. Food Science and Technology. (41) 2051-2056

Quintas M, Guimarães C, Baylina J, Brandão TRS, Silva CM. (2007). Multiresponse Modeling of the Caramelisation Reaction. Innovative Food Science and Emerging Technologies (8) 306315.

Rahayu WP dan Arpah. (2003). Penetapan Kadaluwarsa Produk Industri Kecil Pangan. Bogor : Departemen Teknologi dan Ilmu Pangan IPB.

Rahayu L. (2013). Pengaruh Penambahan Agar-Agar Terhadap Karakteristik Selai Apel Hijau (Mallus sylvestris mill) Lembaran. Proyek Akhir. Program Studi Pendidikan Teknologi Agroindustri FPTK UPI Bandung.

Ramadan, W. (2011). Pemanfaatan Agar-Agar Tepung sebagai Texturizer Pada Formulasi Selai Jambu Biji Merah (Psidium Guajava L.) Lembaran dan Pendugaan Umur Simpannya. IPB: Bogor.

Syah, D. (2012). Pengantar Teknologi Pangan. IPB Press: Bogor.

Syarief dan Halid Y. (1993). Teknologi Pengemasan Pangan. Arcan. Bandung

Winarno FG. (2008). Kimia Pangan dan Gizi. Bogor : MBrio Press. Hal 41-55.

Yenrina R, Hamzah N, dan Zilvia R. (2009). Mutu Selai Lembaran Campuran Nenas (Ananas comusus) dengan Jonjot Labu Kuning (Cucurbita moschata). Jurnal Pendidikan dan Keluarga. 